\title{
Ideal Time of Vaginal Misoprostol Administration in Nulliparous Women Undergoing Office Hysteroscopy: a Randomized Double Blind Placebo Controlled Study
}

\author{
Ahmed Abdelmaguid Mohammed ${ }^{1 *}$ MD, Ismail Talaat Elgarhy ${ }^{1}$ MD, Ahmed Samy Amer ${ }^{1}$ MD \\ and Ashraf Hamdy Mohammed ${ }^{1}$ MD.
}

\author{
*Corresponding Author: \\ Ahmed Abdelmaguid Mohammed \\ abo_gouda87@yahoo.com
}

Received for publication February 26, 2020; Accepted October 2, 2020; Published online October 2, 2020.

Copyright 2020 The Authors published by Al-Azhar University, Faculty of Medicine, Cairo, Egypt. All rights reserved. This an openaccess article distributed under the legal terms, where it is permissible to download and share the work provided it is properly cited. The work cannot be changed in anyway or used commercially.

doi: 10.21608/aimj.2020.24462.1150

${ }^{1}$ Obstetrics and Gynecology Department, Faculty of Medicine, Al-Azhar University,Cairo,Egypt.

Disclosure: The authors have no financial interest to declare in relation to the content of this article. The Article Processing Charge was paid for by the authors.

Authorship: All authors have a substantial contribution to the article.

\begin{abstract}
Background: Hysteroscopy had the process of viewing, operating in the endometrial from a transapproach.

Aim of the work: to detect ideal time of misoprostol administration for priming in nulliparous cases prior by comparing between giving 400microgram 3hours, 6hours, 12hours before hysteroscopy.

Patients and Methods: randomized double-blind placebo-controlled study. This study had done on 198 cases to whom hysteroscopy had done as a part of investigation of (infertility, recurrent miscarriage or abnormal uterine bleeding). Those cases divided into three gatherings each gathering 66 cases, Gathering A, received $400 \mu \mathrm{gm}$ misoprostol $12 \mathrm{hours}$ before hysteroscopy, placebo 6hours, 3hours before hysteroscopy. Gathering B received $400 \mu \mathrm{gm}$ misoprostol 6hours before hysteroscopy, placebo 12 hours, 3hours before hysteroscopy. Gathering $\mathrm{C}$ received $400 \mu \mathrm{gm}$ misoprostol 3hours before hysteroscopy, placebo 12hours, 6hours before hysteroscopy. Our main outcome measures had score(visual analogue scale), procedural time in minutes, bleeding, also to detect side critical of misoprostol, complication of its use.

Results: In gathering A which received $400 \mu \mathrm{gm}$ misoprostol 12hours, score had lower(2.6 \pm 1.3$)$ compared to gathering B(5.3 \pm 1.3$)$ compared to gathering $\mathrm{C}(7.3 \pm 1.2)$. Procedural time had shorter in gathering $\mathrm{A}(2.7 \pm 0.9)$ compared to gathering $\mathrm{B}(5.2 \pm 1.2)$ compared to gathering $\mathrm{C}(7.4 \pm 1.3)$, entry had easier in gathering $\mathrm{A}(4.2 \pm 0.7)$ compared to gathering $\mathrm{B}(3.5 \pm 0.5)$ compared to gathering $\mathrm{C}(2.5 \pm 0.6)$, baseline dilatation had greater in gathering $\mathrm{A}(5.9 \pm 0.8)$ compared to gathering $\mathrm{B}(4.7 \pm 1.1)$ compared to gathering $\mathrm{C}(3.9 \pm 0.8)$ bleeding had least in gathering A compared to gathering $\mathrm{B}$ compared to gathering $\mathrm{C}$ case acceptability had higher in gathering $\mathrm{A}(4.2 \pm 0.7)$ compared to gathering $\mathrm{B}(3.5 \pm 0.5)$ compared to gathering $\mathrm{C}(2.5 \pm 0.6)$. No complication detected in both gatherings.

Conclusion: use of $400 \mu \mathrm{gm}$ misoprostol 12 hours had better than using it 6hours, 3hours in facilitating ripening with minimal side critical without use of anesthesia. it decreases score, decrease procedure duration, increase ease of entry, higher case acceptability, with minimal side critical.
\end{abstract}

Keywords: hysteroscopy; misoprostol; primin 
The synthetic analogue of prostaglandin E1, misoprostol, had the agent used most often for preparation prior ${ }^{7}$.

It could be given orally, vaginally, sublingually, buccally, or rectally ${ }^{8-10}$.

The route appears to be superior to the oral route ${ }^{11}$.

Based on the available evidence on the use of misoprostol prior, the optimal time of misoprostol administration prior to the hysteroscopy. So we tried in our study to test for appropriate time by comparing between 3hours, 6hours, 12hours administration prior.

\section{PATIENTS AND METHODS}

Type of the study: Randomized double-blind placebo-controlled study.

Double blinded means that: neither participants nor operator know which intervention would be received.

Setting of the study: This study had conducted at El Sahel Teaching Hospital from October 2017 till October 2018.

Protocol approval by ethics committee: Before the beginning of the study, in accordance with the local regulation followed, the protocol, all corresponding documents had declared for Ethical, Research approval by the Council of Obstetrics, Gynecology Department, Al-Azhar University.

Sample size calculation: We had planning a study of a continuous response variable from 3equal study gatherings. We added $10 \%$ to each gathering to compensate for the dropped cases, so each gathering would be 66 cases.

Case selection: One hundred ninety eight nulliparous cases had subjected with the following

Inclusion criteria: Age-childbearing period or postmenopause from 20-50years, Nulliparous cases, Indication for hysteroscopy; Infertile cases either primary or secondary infertility, Cases with history of recurrent miscarriage, Cases with history of abnormal uterine bleeding.

Exclusion criteria: Contraindications:Any uterine abnormality that would obviate passage of a catheter, marked stenosis, recent pelvic disease, uterine bleeding. Contraindications to prostaglandins.

After obtaining informed consent, all included cases had subjected to: thorough history taking, Full examination, Pelvic ultrasound, Laboratory investigations: Serum cases test: to exclude cases.
Interventions: The cases had divided into 3gatherings randomly, each gathering contained 66cases. Method of randomization: computerized randomization(covariate adaptive randomization) randomization.

First gathering (long interval misoprostol gathering): Two misoprostol (400micrograms) had given vaginally 12 hours prior. Two placebo had given vaginally 6hours, 3hours prior.

Second gathering(intermediate interval misoprostol gathering): Two placebo had given vaginally 12 hours prior. Two misoprostol had given vaginally 6hours prior. Two placebo had given vaginally 3hours prior.

Third gathering(short interval misoprostol gathering): Two placebo had given vaginally 12hours, 6hours prior. Two misoprostol had given vaginally 3hours prior. The placebo had folic acid 500mcg. The hysteroscopy had scheduled in the proliferative menstrual phase from the $5^{\text {th }}$ day to the $14^{\text {th }}$ day of the cycle. Informed written consent had signed by all the cases.

Technique: Case preparation had one of the most important aspects for successful hysteroscopy, thus the procedure had described to every case prior to the examination, each step had explained during the procedure so the cases had an active participants, this helped them to understand the experience, relieved anxiety. The hysteroscope used in this study had that of Karl Storz,(Germany 1996). It had a rigid continuous flow panoramic hysteroscopy $25 \mathrm{~cm}$ in length, $4 \mathrm{~mm}$ in diameter with an outer sheath of $5.5 \mathrm{~mm}$, a 30degree fibro optic lens. The light source used in this study had a metal halide automatic light source from Circon Acmi G71A/Germany with 150watt lamp. A fibro optic cable had connected to the light source. The technique used to provide constant uterine distention had by 3L volume saline bags to dual infusion tubing which had suspended one meter above the case level. Each bag had then wrapped in a pressure infusion cuff similar to that used in BP to reach a pressure of $150-200 \mathrm{mmHg}$. The tubing had connected to the hysteroscope. It had helpful, more comfortable for the operator to sit on a low chair, to elevate the foot of the examination table to perform the procedure. After the case had installed in the lithotomy position then the gynecologist used sterile gloves, checking the flow of the distention medium, the hysteroscope had introduced under direct vision into the cervix without the use of anesthesia or analgesia, using a specific technique. No dilatation had done. 


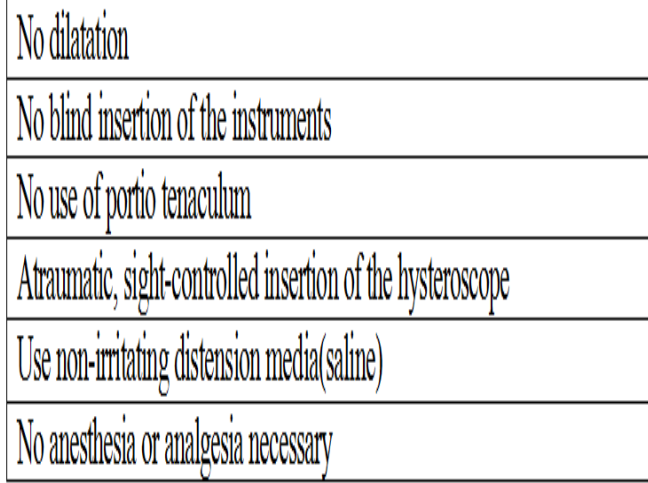

Table 1: Technique of a traumatic diagnostic hysteroscopy:

The outcomes that had measured: The level of pelvic had rated according to a 10 -point visual analogue
scale(VAS). The VAS had applied immediately after the procedure ended. Ease of entry of the cervix recorded on a 5-point Likert scale(Likert 1932): very difficult $=1$, difficult $=2$, fair $=3$, easy $=4$, very easy $=5$. Baseline width at the beginning of the procedure had assessed by the largest number of Hegar dilator that could be inserted into the cervix without resistance. The bleeding during the procedures had assessed whether if there had no or moderate or severe bleeding. The time from introduction through the external os, the visualization of the uterine had recorded in minutes. Any complications or side critical to perform hysteroscopy.

Statistical analysis: Data had then transferred to the IBM SPSS Statistics for Windows, Version 23.0. Armonk, NY: IBM Corp.

RESULTS

\begin{tabular}{|c|c|c|c|c|c|c|c|}
\hline Demographic DATA & $\begin{array}{c}\text { Gathering A } \\
\quad(\mathrm{n}=66)\end{array}$ & $\begin{array}{c}\text { Gathering B } \\
(\mathrm{n}=66)\end{array}$ & $\begin{array}{c}\text { Gathering } \mathrm{C} \\
(\mathrm{n}=66)\end{array}$ & P Value & $A^{*} B$ & $A^{*} \mathrm{C}$ & $\mathrm{B}^{*} \mathrm{C}$ \\
\hline $\begin{array}{c}\text { Age: } \\
\text { Mean } \pm S D \\
\text { Range }\end{array}$ & $\begin{array}{c}33.6 \pm 8.1 \\
20-49\end{array}$ & $\begin{array}{c}33.6 \pm 7.3 \\
22-50\end{array}$ & $\begin{array}{c}32.7 \pm 6.8 \\
22-50\end{array}$ & 0.753 & 0.999 & 0.801 & 0.781 \\
\hline $\begin{array}{c}\text { Duration of marriage: } \\
\text { Mean } \pm S D \\
\text { Range }\end{array}$ & $\begin{array}{c}10.4 \pm 5.7 \\
2-25\end{array}$ & $\begin{array}{c}10.5 \pm 5.6 \\
3-25\end{array}$ & $\begin{array}{c}9.9 \pm 5.2 \\
4-25\end{array}$ & 0.817 & 0.991 & 0.883 & 0.819 \\
\hline $\begin{array}{l}\text { Gravidity: } \\
\text { MG } \\
\text { NG }\end{array}$ & $\begin{array}{l}30(45.5 \%) \\
36(54.5 \%)\end{array}$ & $\begin{array}{l}28(42.4 \%) \\
38(57.6 \%)\end{array}$ & $\begin{array}{l}39(59.1 \%) \\
27(40.9 \%)\end{array}$ & 0.125 & 0.726 & 0.117 & 0.055 \\
\hline $\begin{array}{c}\text { Prev. procedure: } \\
\text { Cerclage } \\
\text { Cautery } \\
\text { Biopsy } \\
\text { No previous technique }\end{array}$ & $\begin{array}{c}15(22.7 \%) \\
14(21.2 \%) \\
3(4.5 \%) \\
34(51.6 \%)\end{array}$ & $\begin{array}{c}18(27.3 \%) \\
10(15.2 \%) \\
1(1.4 \%) \\
37(56.1 \%)\end{array}$ & $\begin{array}{c}19(28.8 \%) \\
6(9.1 \%) \\
3(4.5 \%) \\
38(57.6 \%)\end{array}$ & 0.533 & 0.559 & 0.273 & 0.571 \\
\hline $\begin{array}{l}\text { Indications: } \\
\text { Infertility } \\
\text { Abortion } \\
\text { Bleeding }\end{array}$ & $\begin{array}{l}26(39.4 \%) \\
18(27.3 \%) \\
22(33.3 \%)\end{array}$ & $\begin{array}{l}26(39.4 \%) \\
19(28.8 \%) \\
21(31.8 \%)\end{array}$ & $\begin{array}{r}31(47 \%) \\
22(33.3 \%) \\
13(19.7 \%)\end{array}$ & 0.455 & 0.975 & 0.207 & 0.281 \\
\hline
\end{tabular}

Table 2: Comparison between gatherings as regard demographic data. 


\begin{tabular}{|c|c|c|c|c|c|c|c|}
\hline Outcome Measures & $\begin{array}{c}\text { Gathering } \\
\text { A }\end{array}$ & $\begin{array}{c}\text { Gathering } \\
\text { B }\end{array}$ & $\begin{array}{c}\text { Gathering } \\
\text { C }\end{array}$ & $\begin{array}{c}\mathrm{P} \\
\text { VALUE }\end{array}$ & A, B & $\mathrm{A}, \mathrm{C}$ & $\mathrm{B}, \mathrm{C}$ \\
\hline $\begin{array}{c}\text { Level of according to VAS: } \\
\text { Mean } \pm \text { SD } \\
\text { Range }\end{array}$ & $\begin{array}{c}2.6 \pm 1.3 \\
1-5\end{array}$ & $\begin{array}{c}5.3 \pm 1.3 \\
3-9\end{array}$ & $\begin{array}{c}7.3 \pm 1.2 \\
5-10\end{array}$ & $<0.001$ & $<0.001$ & $<0.001$ & $<0.001$ \\
\hline $\begin{array}{l}\text { Ease of entry according to } \\
\text { LIKERT scale } \\
\text { Mean } \pm \text { SD } \\
\text { Range }\end{array}$ & $\begin{array}{c}4.2 \pm 0.7 \\
1-5\end{array}$ & $\begin{array}{c}3.5 \pm 0.5 \\
3-4\end{array}$ & $\begin{array}{c}2.5 \pm 0.6 \\
1-4\end{array}$ & $<0.001$ & $<0.001$ & $<0.001$ & $<0.001$ \\
\hline $\begin{array}{c}\text { Baseline dilatation by Hegar } \\
\text { dilator } \\
\text { Mean } \pm \text { SD } \\
\text { Range }\end{array}$ & $\begin{array}{c}5.9 \pm 0.8 \\
5-7\end{array}$ & $\begin{array}{c}4.7 \pm 1.1 \\
3-6\end{array}$ & $\begin{array}{c}3.9 \pm 0.8 \\
3-5\end{array}$ & $<0.001$ & $<0.001$ & $<0.001$ & $<0.001$ \\
\hline $\begin{array}{l}\text { Duration of procedure in } \\
\text { minutes } \\
\text { Mean } \pm \text { SD } \\
\text { Range }\end{array}$ & $\begin{array}{c}2.7 \pm 0.9 \\
1-4\end{array}$ & $\begin{array}{c}5.2 \pm 1.2 \\
3-8\end{array}$ & $\begin{array}{c}7.4 \pm 1.3 \\
5-10\end{array}$ & $<0.001$ & $<0.001$ & $<0.001$ & $<0.001$ \\
\hline $\begin{array}{c}\text { bleeding: } \\
\text { Mild } \\
\text { Moderate } \\
\text { No }\end{array}$ & $\begin{array}{c}3(4.6 \%) \\
1(1.5 \%) \\
62(93.9 \%)\end{array}$ & $\begin{array}{c}12(18.2 \%) \\
5(7.6 \%) \\
49(74.2 \%)\end{array}$ & $\begin{array}{l}30(45.5 \%) \\
10(15.2 \%) \\
26(39.3 \%)\end{array}$ & $<0.001$ & 0.008 & $<0.001$ & $<0.001$ \\
\hline $\begin{array}{l}\text { Case acceptability: } \\
\qquad \begin{array}{c}\text { Mean } \pm \text { SD } \\
\text { Range }\end{array}\end{array}$ & $\begin{array}{c}4.2 \pm 0.7 \\
1-5\end{array}$ & $\begin{array}{c}3.5 \pm 0.5 \\
3-4\end{array}$ & $\begin{array}{c}2.5 \pm 0.6 \\
1-4\end{array}$ & $<0.001$ & $<0.001$ & $<0.001$ & $<0.001$ \\
\hline
\end{tabular}

Table 3: Comparison between gatherings as regard outcome measures: Data had expressed as number \pm standard deviation, percent(\%)

F- ANOVA test;

\begin{tabular}{|c|c|c|c|c|c|c|c|}
\hline $\begin{array}{l}\text { Misoprostol side } \\
\text { critical }\end{array}$ & $\begin{array}{l}\text { Gathering A } \\
\qquad(n=66)\end{array}$ & $\begin{array}{l}\text { Gathering B } \\
\qquad(n=66)\end{array}$ & $\begin{array}{c}\text { Gathering C } \\
\qquad(n=66)\end{array}$ & $\begin{array}{c}\mathbf{P} \\
\text { valu } \\
\text { e }\end{array}$ & $A * B$ & $A^{*} C$ & $\mathrm{~B}^{*} \mathrm{C}$ \\
\hline Pain & $5(7.6 \%)$ & $10(15.2 \%)$ & $12(18.2 \%)$ & \multirow{4}{*}{$\begin{array}{c}0.12 \\
5\end{array}$} & \multirow{4}{*}{$\begin{array}{c}0.21 \\
7\end{array}$} & \multirow{4}{*}{$\begin{array}{c}0.05 \\
4\end{array}$} & \multirow{4}{*}{$\begin{array}{c}0.71 \\
7\end{array}$} \\
\hline Nausea & $3(4.5 \%)$ & $7(10.6 \%)$ & $9(13.6 \%)$ & & & & \\
\hline Diarrhea & $2(3 \%)$ & $3(4.5 \%)$ & $5(7.6 \%)$ & & & & \\
\hline No Side critical & $56(84.8 \%)$ & $46(69.7 \%)$ & $40(60.6 \%)$ & & & & \\
\hline
\end{tabular}

Table 4: Comparison between gatherings as regard side effect of misoprostol.

Data had expressed as number, percent(\%) 


\section{DISCUSSION}

This study showed that giving 400microgram misoprostol 12hours prior (gathering A) had better than giving it 6hours(gathering B), 3hours(gathering C) prior as level of pelvic had lowest in gathering $\mathrm{A}$ followed by gathering $\mathrm{B}$ followed by gathering $\mathrm{C}$, ease of pelvic entry had easier in gathering $A$ followed by gathering $\mathrm{B}$ followed by gathering $\mathrm{C}$, baseline dilatation had greater in gathering $\mathrm{A}$ followed by gathering $\mathrm{B}$ followed by gathering $\mathrm{C}$, time of the procedure had shorter in gathering $\mathrm{A}$ followed by gathering $\mathrm{B}$ followed by gathering $\mathrm{C}$, bleeding had least in gathering $\mathrm{A}$, followed by gathering $\mathrm{B}$, then gathering $\mathrm{C}$. Misoprostol related side effect as fever, abdominal pain, nausea, diarrhea had minimal, there had no critical difference between the three gatherings.

Fouda et al., they compared 400mcg misoprostol 12h, 3h before hysteroscopy, they found that misoprostol administration 12hours before hysteroscopy ${ }^{12}$.

Bastu et al., they found that $200 \mu$ g, $400 \mu g$, critical facilitated the procedure of $\mathrm{OH}$ compared to the controls as entry had easier; procedural time had shorter; baseline width had larger, scoring had lower ${ }^{13}$.

Bakas et al, administered 200 $\mu$ g oral misoprostol to one gathering(12hours before), 200 $\mu$ g misoprostol to

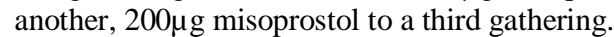

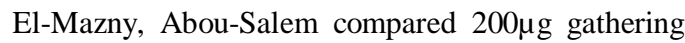
in which placebo had not used; procedure time had shorter, case acceptability had higher, scoring had lower in the gathering, which had in line with our findings ${ }^{15}$.

Preutthipan, Herabutya, showed that misoprostol, resulted in critical priming before hysteroscopy in non cases. They reported greater dilation, decreased resistance, or curettage with oral or misoprostol ${ }^{16}$.

El Khayat et al. compared the critical of isosorbide mononitrate(I.M.N), misoprostal for priming before the hysteroscopy, there had a critical difference between I.M.N, misoprostol with regard to the baseline dilatation( $5 \mathrm{~mm}$ for I.M.N, $8 \mathrm{~mm}$ for misoprostol), duration of dilatation(73s for I.M.N, 49s for misoprostol) ${ }^{17}$.

Mulayim et al. two gatherings of cases who received sublingual misoprostol or placebo before hysteroscopy had compared with each other. Dilatation time had higher in placebo gathering. Furthermore, tearing had occurred more often in placebo gathering than in misoprostol gathering ${ }^{\mathbf{1 8}}$.

Batukan et al. reported that $400 \mu \mathrm{g}$ administration of misoprostol had more critical than the oral route with the same dose for preoperative ripening in premenopausal cases in terms of extent of initial width, percentage of cases requiring dilatation, procedural time as well as complications during procedure, associated side critical ${ }^{20}$.
Preutthipam \& Herabutya compared the critical of misoprostol more critical technique, suggested to use misoprostol for priming instead of dinoprostone ${ }^{23}$.

Choksuchat et al. suggested that $400 \mathrm{mg}$ oral misoprostol had as critical as $200 \mu \mathrm{g}$ route for ripening ${ }^{24}$.

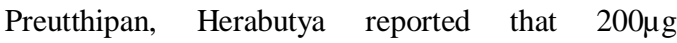
misoprostol 9-10hours before the procedure lessens resistance, facilitates the procedures ${ }^{25}$.

Bahamondes et al. found that pretreatment with intra100mcg of misoprostol after IUD insertion failure in 104cases 4 -10hours before $2^{\text {nd }}$ attempt had critical better than placebo(RCT) ${ }^{\mathbf{2 6}}$.

But this had not in agreement with a randomized controlled study which revealed that $400 \mu \mathrm{g}$ misoprostol administered vaginally 6hours before hysteroscopy had not critical in reducing experienced during hysteroscopy ${ }^{27}$.

In addition, sequential doses of $400 \mathrm{mg}$ of oral misoprostol at 12-24hours before technique did not demonstrate any advantage in so far as dilation ${ }^{28}$.

Fernandez et al. who gave cases three different doses of misoprostol in either 200,400, or $800 \mu$ g 4hours before $\mathrm{OH}$, they found no critical difference ${ }^{29}$.

Bisharah et al. compared the effect of $100 \mu \mathrm{g}$ of sublingual misoprostol administered $12 \mathrm{~h}$ prior to operative hysteroscopy in 20cases to placebo, found no difference in facilitation of dilatation. Similarly, demonstrated no difference in ease of dilatation following administration of $800 \mu \mathrm{g}$ of misoprostol administered at least $5 \mathrm{~h}$ prior compared to placebo in postmenopausal cases ${ }^{30}$.

\section{CONCLUSION}

Hysteroscopy had an essential tool for uterine environment assessment. Misoprostol had a good ripening agent, had critical in changing the character of the cervix from harder, softer. This study showed that giving 400microgram misoprostol 12hours prior had better than giving it 6hours, 3hours prior.

\section{REFERENCES}

1. Golan A, Eilat E, Ron-El R, Herman A, Soffer Y, Bukovsky I: Hysteroscopy is superior to hysterosalpingography in infertility investigation. Acta Obstet Gynecol Scand.1996, 75: 654-6.

2. Isaacson $\mathrm{K}$ : Office hysteroscopy: a valuable but under-utilized technique. Curr Opin Obstet Gynecol, 2002., 14(4):381-5.

3. Campo R, Molinas CR and Rombauts L : Prospective multicentre randomized controlled trial to evaluate factors influencing the success rate of office diagnostic hysteroscopy. Hum Reprod.2005, 20: 258-63. 
4. El-Mazny A and Abou-Salem N : A double-blind randomized controlled trial of vaginal misoprostol for cervical priming before outpatient hysteroscopy. Fertil Steril.2011, 96 (4): 962-5.

5. Lin YH, Hwang JL, Seow KM, Huang LW, Chen HJ, Hsieh BC : Laminaria tent vs vaginal misoprostol for cervical priming before hysteroscopy: Randomized study. J Minim Invasive Gynecol.,2009, 16:708-12.

6. Lee YY, Kim TJ, Kang H, Choi CH, Lee JW and Kim BG : The use of misoprostol before hysteroscopic surgery in nonpregnant premenopausal women: a randomized comparison of sublingual, oral and vaginal administrations. Hum Reprod.2010, 25 (8): 1942-8.

7. Preutthipan S and Herabutya $\mathrm{Y}$ : A randomized comparison of vaginal misoprostol and dinoprostone for cervical priming in nulliparous women before operative hysteroscopy. Fertil Steril.2006, 86: 990-4.

8. Fa_undes A and Weeks A : Misoprostol in obstetrics and gynecology. Int J Gynecol Obstet.2007, 99:S156-9.

9. Saav I, Aronsson A, Marions L, Stephansson O and Gemzell-Danielsson K : Cervical priming with sublingual misoprostol prior to insertion of an intrauterine device in nulliparous women: a randomized controlled trial. Hum Reprod.2007, 22: 2647-52.

10. Crane JM and Healey 5 : Use of misoprostol before hysteroscopy: a systemic review. J Obstet Gynecol Can.2006, 28 (5): 373-9.

11. Batukan C, Ozgun MT, Ozcelik B, Aygen E, Sahin $\mathrm{Y}$ and Turkyilmaz $\mathrm{C}$ : Cervical ripening before operative hysteroscopy in premenopausal women: a randomized, double-blind, placebocontrolled comparison of vaginal and oral misoprostol. Fertil Steril.2008, 89: 966-73.

12. Usama M.Fouda,Sherine H.Gadallah,Hesham S.Elshaer: Optimal timing of misoprostol administration in nulliparous women undergoing office hysteroscopy a randomized double-blind placebo-controlled study.Fertility and sterility.2016,106(1):196-201.

13. Bastu E, Celik C, Nehir A, Dogan M, Yuksel B, Ergun B :Cervical priming before diagnostic operative hysteroscopy in infertile women: a randomized, double-blind, controlled comparison of 2 vaginal misoprostol doses. Int Surg.2013, 98(2): 140-4
14. Bakas P, Hassiakos D and Liapis A : Misoprostol for cervical ripening before diagnostic hysteroscopy in nulliparous women. Int $\mathrm{J}$ Gynaecol Obstet.2012, 116 (3): 263-4.

15. El-Mazny A and Abou-Salem N : A double-blind randomized controlled trial of vaginal misoprostol for cervical priming before outpatient hysteroscopy. Fertil Steril.2011, 96 (4): 962-5.

16. Preutthipan S and Herabutya Y : Vaginal misoprostol for cervical priming before operative hysteroscopy: a randomized controlled trial. Obstet Gynecol.2010, 96:890.

17. El-khayat W, Maged A, Omar H : A comparative study between isosorbidemononitrate versus misoprostol prior to hysteroscopy. Mid East FertilSoc J.2010, 15:278-80.

18. Mulayim B, Celik NY, Celik G, Bagis T, Zeyneloglu HB : Sublingual misoprostol for cervical ripening before diagnostichysteroscopy in premenopausal women: a randomized, double blind, placebo-controlled trial.Fertil Steril.2010, 93:2400-4.

19. Lee YY, Kim TJ, Kang H, Choi CH, Lee JW and Kim BG : The use of misoprostol before hysteroscopic surgery in nonpregnant premenopausal women: a randomized comparison of sublingual, oral and vaginal administrations. Hum Reprod.2010, 25 (8): 1942-8.

20. Batukan C, Ozgun MT, Ozcelik B, Aygen E, Sahin Y and Turkyilmaz C : Cervical ripening before operative hysteroscopy in premenopausal women: a randomized, double-blind, placebocontrolled comparison of vaginal and oral misoprostol. Fertil Steril.2008, 89: 966-73.

21. Da Costa AR, Pinto-Neto AM, Amorim M, Paiva LH, Scavuzzi A, Schettini J : Use of misoprostol prior to hysteroscopy in postmenopausal women: a randomized, placebo-controlled clinical trial. J Minim Invasive Gynecol.2008, 15(1):67-73.

22. Oppegaard KS, Nesheim BI, Istre O, Qvigstad E: Comparison of selfadministered vaginal misoprostol versus placebo for cervical ripening prior to operative hysteroscopy using a sequential trial design. BJOG.2008, 115:663. e1-663e9.

23. Preutthipan S and Herabutya Y : A randomized comparison of vaginal misoprostol and dinoprostone for cervical priming in nulliparous women before operative hysteroscopy. Fertil Steril.2006, 86: 990-4. 890 \pm 894 . 
24. Choksuchat C, Cheewadhanaraks S, Getpook C, Wootipoom V, Dhanavoravibul K : Misoprostol for cervical ripening in non-pregnant women: a randomized double-blind controlled trial of oral versus vaginal regimens. Hum Reprod.2006, 21:2167-70.

26. Esin S, Baser E, Okuyan E and Kucukozkan T : Comparison of 44. Bahamondes L, Díaz J, Marchi NM et al. (2015): Performance of copper intrauterine devices when inserted after an expulsion. Hum Reprod.2013, 10:1577.

27. Hassa $\mathrm{H}$, Aydin $\mathrm{Y}$, Oge $\mathrm{T}$ and Cicek $\mathrm{K}$ : Effectiveness of vaginal misoprostol and rectal nonsteroidal antiinflammatory drug in vaginoscopic diagnostic outpatient hysteroscopy in primarily infertile women: double-blind, randomized, controlled trial. J Minim Invasive Gynecol.2013, 20: 880-5.

28. Thomas JA, Leyland N, Durand N and Windrim RC : the use of oral misoprostol as a cervical ripening agent in operative hysteroscopy: adouble blind, placebo controlled trial. Am J Obstet Gynecol.2002, 86 (5): 876-9.
25. Preutthipan S and Herabutya Y : Vaginal misoprostol for cervical priming before operative hysteroscopy: a randomized controlled trial. Obstet Gynecol.2000, 96: 890-4.

29. Fernandez H, Alby JD, Tournoux C, ChauveaudLambling A, DeTayrac R and Frydman R : Vaginal misoprostol for cervical ripening before operative hysteroscopy in pre-menopausal women: a double-blind, placebo-controlled trial with three dose regimens. Hum Reprod.2004, 19 (7): 1618-21

30. Bisharah $\mathrm{M}$, Al-Fozan $\mathrm{H}$, Tulandi $\mathrm{T}$ : A randomized trial of sublingual misoprostol for cervical priming before hysteroscopy. J Am Assoc Gynecol Laparosc.2003, 10:390-1.

31. Singh K, Fong YF, Prasad RN d RN, Dong F : Randomized trial to determine optimal dose of vaginal misoprostol for pre abortion cervical priming. Obstet Gynecol.1998, 92:795-8 